\title{
DOMINANT TECHNOLOGICAL DISCOURSES IN ACTION: PARADIGMATIC SHIFTS IN SENSE MAKING IN THE IMPLEMENTATION OF AN ERP SYSTEM
}

\author{
Jeremy Rose \\ Department of Computer Science \\ Aalborg University \\ Aalborg \\ Denmark
}

Pernille Kræmmergaard

Centre for Industrial Production

Aalborg University

Aalborg

Denmark

\begin{abstract}
In an implementation of an ERP system in a large Danish production company, the ways in which the participants made sense of the project changed appreciably during the course of the project. At the start of the project, the predominant mode of thinking was classical, with many actors thinking of the implementation as a standard IT project. Later in the project, this way of thinking had changed: the majority viewed the implementation as an organizational change program. Clearly the experience of the project had changed the sense making of the participants to some extent. We used three theoretical frameworks to investigate and explain this change. Technological frames (Orlikowski and Gash 1994) helped us distinguish the different styles of sense making, but bound particular social groups to particular frames in a way that was not consistent with the empirical situation. Alvesson and Willmott's (1996) levels of discourse provided a richer picture of interlinking and evolving styles of sense making, and of actors' fluency in moving between one and another, but provided no

The original version of this chapter was revised: The copyright line was incorrect. This has been corrected. The Erratum to this chapter is available at DOI: 10.1007/978-0-387-35634-1_28


explanation of how or why one discourse should take over from another. In order to explain this change, it was necessary to add actions and outcomes to the picture, and for this a later theoretical contribution of Orlikowski (2000) was useful. In the practice lens, Orlikowski extends her work on structuration theory and technology. Here sense making (structure) and action are dependent upon each other in an emergent process. Since none of these theoretical perspectives offered a convincing explanation of the change in sense making at Omega, it was necessary to construct a new theoretical model in the light of our analysis. Now it was possible to understand how actions (taken in the light of the dominant technological discourse about the ERP implementation) produced outcomes perceived as unfavorable, and how an alternative discourse providing more tolerable and convenient sense making took over.

\section{INTRODUCTION}

Interpretative literature about IS contains many theoretical accounts of how actors make sense of information technology in organizations. The literature builds on cognitive accounts of the endowment of meaning (Berger and Luckmann 1966; Weick 1979) and their translation into an organizational context (Weick and Bougon 1986). These accounts focus on language and discourse as an important vehicle for the negotiation of meaning. Various formulations of shared conceptual structures in an organizational context have been offered, including cognitive maps (Eden 1988), frames (Goffman 1974), Weltanschauung (Checkland and Davies 1986), mental models (Argyris and Schön 1978), paradigms (Kuhn 1962), and thought worlds (Douglas 1987). Shared conceptual structures also can be studied in terms of the discourses that support them (Alvesson and Karreman 2000; Edwards 1995; Heracleous and Barrett 2001). The intellectual tradition of social constructivism underpins the social shaping of technology school (Bijker et al. 1987; Bijker and Law 1994; Grint and Woolgar 1997; MacKenzie and Wajcman 1985), in which shared patterns of sense making are understood to influence the construction and use of technology. Similarly, the sociological study of technology school (Callon 1987; Latour 1991; Law 1991; Monteiro and Hanseth 1996) show how shared understandings can be inscribed into technology. Structurational accounts (Barley 1986; Orlikowski 1992, 2000; Orlikowski and Robey 1991) relate sense making to ongoing social practice in technology development and use. These structurational accounts focus not only on structures of sense making, but their relationship to actions and dynamic patterns of social behavior. Similarly, some recent strands 
of the literature relate sense making to other dynamic concepts such as emergence (Truex et al. 1999) and drift (Ciborra 2000).

When the implementation of an ERP system in a large Danish production company (here referred to as Omega) was planned, many of those concerned shared reasonably conventional sense making about IT systems, their function in an organization, and the way they should be implemented. This view, which we shall refer to as a classical view, can also be found in the press and is widespread in the academic literature. Three years later, after many turbulent and demanding experiences, the majority of the participants had changed the way they made sense of the implementation. The dialogues, narratives, and interpretations were considerably different, and in some ways contradictory to the perspectives that had been held earlier. A simple (slightly technologically deterministic) explanation of this phenomenon could be that the new technology (the ERP system) was different in kind and/or scope from previous systems and that the experience of implementing it was therefore different. Different experiences caused changes in perspectives. However it seemed that both ways of thinking about the technology were always available to members of the organization, and always present in the organization. It was more the case that one perspective had been dominant at one time, but lost its dominance to another perspective. The research objective of this paper is thus to explain the change in sense making of the ERP implementation at Omega.

In searching for suitable theories to explain this change (evident from the empirical data), we chose three with the potential ti explain at least parts of the story. We chose technological frames (Orlikowski and Gash 1994) in order to sharply delineate the contrasting technology perspectives. We chose organizational discourses (Alvesson and Karreman 2000; Borenreider 1998; Edwards 1995; Heracleous and Barrett 2001) in order to analyze the relationships between the different technology perspectives. Finally we chose the practice lens of Orlikowski (2000) in order to study the change in the technology perspectives. This allows three complementary analyses of the ERP implementation at Omega, which both develop different aspects of the implementation and build upon each other. None of the theoretical models or analyses offered a complete explanation, but discussion and comparison of theory and analyses leads to the generation of a reasonable understanding of the change in sense making. This is finally generalized back to theory in the form of a theoretical model.

\section{METHODOLOGY}

The research method can be classified as a longitudinal in-depth interpretive ethnographic study, and the philosophical base is critical hermeneutics (Myers 
1997). Critical hermeneutics recognizes that the history and context are important factors to take into account when trying to understand social phenomena. The data was collected in accordance with these principles between January 1996 and January 2001, using detailed observation of actions in the field and unstructured interviews. One of the researchers observed (but did not participate in) all of the ERP management meetings, as well as daily work within the organization and training classes. Observations and unstructured interviews were supplemented with informal social contact with the participants, and with review of written materials. Interviews were conducted at all levels of the organization: senior managers, the ERP manager, members of the implementation group, the internal consultant, super-users, and regular users. The unstructured interviews were carried out in two rounds, the first in spring 1996, and the second in autumn 1997 (more than 6 months after the ERP system implementation). Unstructured interviews with the project manager continued throughout the research period. Sense making of the ERP project was found to have changed at the second round of interviews.

Walsham (1995), following Eisenhardt (1989), suggests that theory may be involved in an interpretive study in three ways:

1. As an initial guide to design and data collection

2. As part of an iterative process of data collection and interpretation

3. As a final product of the research

In this research, theory was used as part of an iterative process of data collection and interpretation, and also forms part of the final product of the research. There may be a problem in generalizing from case study research, where depth is substituted for breadth, but Walsham (1995) suggests that four types of generalization are possible. Concepts may be developed, or theory may be generated. Specific implications in particular domains of action may be drawn; such generalizations are often formulated as tendencies rather than predictions. Learning from interpretative case studies may also be of a less focused nature, which is not well described by the preceding categories; Walsham terms this learning rich insight.

In this research, we choose to first present the story in a relatively value free and uninterpreted manner (of course the selection and ordering of material is in itself an exhibition of value assignation and interpretation). However, this reading stands as a text or story line which is then open to various theoretical analyses. This process is akin to a form of deconstruction, which turns and contrasts a text while holding its meaning in a deferred or not quite complete state, similar to Derrida's (1982) notion of différance or Hopper's (1987) linguistic emergence. Concepts kept in play, repeatedly turned and reconsidered, may yield fresh insights and the surfacing and unfreezing of implicit 
assumptions. Thus the different analyses allow the examination of different aspects and further layers of interpretation, as well as comparison of theoretical concepts. It also allows the reader to judge whether the analyses have been made in a justifiable way, and to follow the process of developing argumentation.

The study seeks to develop a specific explanation of a set of phenomena (the change in sense making at Omega) in a particular domain (ERP implementation). It is couched mainly in terms drawn from existing theory. This explanation remains, however, a theoretical explanation of one particular situation, and further research would be necessary to generalize this explanation to other situations.

\section{THREE THEORETICAL FRAMEWORKS}

This section describes three different theoretical accounts of sense making: focusing on distinguishing different versions of sense making about technology (technological frames), the relationship between those different versions (discourse), and the change between different versions (practice lens). Comparison of the theoretical frameworks is deferred until later.

\subsection{Technological Frames}

Orlikowski and Gash (1994) advanced the idea of technological frames as a way of understanding shared cognitive structures about technology in organizations. Frames (of reference) are one of a number of theoretical devices derived from cognitive psychology, organizational behavior, and social theory, which try to explain how individuals in social situations share some commonalty in their interpretations, ideas and beliefs. While recognizing that individuals' frames are different, Orlikowski and Gash use the term technological frame to identify the "assumptions, expectations and knowledge" organization members use to understand technology:

understanding members of a social group come to have of particular technological artefacts...[including] not only the technology itself, but the specific conditions, applications, and consequences of that technology in particular contexts.

These understandings are clearly delineated from any properties that the technologies may or may not be assumed to have in themselves. One may, therefore, expect to analytically identify a number of technology frames held by different social groups or communities of practice in an organization, which may 
be congruent, in the extent to which they converge and agree, or incongruent if they differ substantially. Orlikowski and Gash further suggest that incongruent technological frames are likely to be associated with "difficulties and conflicts around developing, implementing, and using technologies." Frames are quite likely to be "self-reinforcing, even to the point of rejecting knowledge that does not fit their system of meaning" and are not necessarily self consistent. In their analysis of the implementation of Notes in a company they name Alpha, they concentrate on understandings the technology is (nature of technology), why it was introduced (technology strategy), and how it is used to create various changes in work (technology use). The social groups studied are technologists (the technical staff) and users. Orlikowski and Gash show how the different technological frames of technologists and users diverge (the technologists trying to implement a powerful and transformative group working tool, the users accepting a much more limited and rather irrelevant personal productivity tool). They also show how the two groups take actions consistent with their technological frames.

\subsection{Discourse}

The word discourse is widely used, but often imprecisely defined. Our use of the term is consistent with Edwards (1995, p. 34):

the entire field of signifying or meaningful practices: those social interactions-material, institutional and linguisticthrough which reality is interpreted and constructed for us and with which human knowledge is produced and reproduced. A discourse, then, is a way of knowledge, a background of assumptions and agreements about how reality is to be interpreted and expressed.

We understand discourse as the way in which an action, a practice, a phenomenon, or a speech act is interpreted and understood. Actors need discourses to organize their world. Discourses are made up of rules and procedures, that construct and legitimate the way actors see things and talk about them. Discourses legitimate certain statements and communicational practices while invalidating others (Casey 1995). Discourses are located in practice, and created and recreated through interaction between actors.

After Alvesson and Karreman (2000), we distinguish between four different levels of discourse: 
1. Micro-discourse

2. Discourse-near

3. Grand-discourse

4. Mega-discourse

Micro-discourse in an organizational setting relates to individual actors; discourse-near relates to a group of actors (or a social group) that share and act under the same discourse. The grand-discourse is the discourse of the organization and the mega-discourse relates to the ruling discourse at the time, which can be on a regional, national, or even international level, which also influences the organization and the interactions within it. The micro-discourses and the discourse-near in an organizational setting interact with each other; during those interactions, new discourses are developed and others disappear. These interactions take place within the grand-discourse, which enables actors to understand what is organizationally legitimate. Interactions within the organization are situated within a regional and national context, which also influences the other discourses. All levels of discourse are emergent and can evolve over time. When a discourse becomes established, it may disappear into the background, becoming more tacit and implicit-an unacknowledged backdrop for understanding and practice.

Many discourses will normally coexist within an organization, and actors will have different discursive orientations, moving between discourses appropriate to different social groups and different situations. Actors may orient themselves consciously or unconsciously toward different (even competing) discourses. They may "bypass the diverse discourses in favor of common action" (Borenreider 1998), put their own discourses in the background in order to interact with other actors in a meaningful and understandable way, perhaps to achieve a temporary goal. Discourses are regarded as being fluid and overlapping, and not a priori bound to social groups, organizational departments, or organizational levels.

Discourses involve shared understandings of language and concepts which facilitate interaction between actors. Actors sharing a discourse can normally be expected to interact easily, since they share each others vocabulary, descriptive process, and interpretations. Interaction between actors without a shared discourse can be much harder, it becomes necessary to define a language and explain interpretations before meaningful communication and interaction is possible. Material objects (such as computer systems) and their interpretation do not stand independent of discourse, and are understood through discourse. It follows that they may be understood differently by actors interpreting them through different discourses. 


\subsection{Practice Lens}

Orlikowski (2000) continues her work with structuration theory by developing what she calls a practice lens for studying technology in organizations. Structuration theory (Giddens 1984) has generated a number of models of technology in organizations (Barley 1986; DeSanctis and Poole 1994; Orlikowski 1992; Orlikowski and Robey 1991; Rose and Scheepers 2001; Walsham 1993). While noting that structuration theory, being dynamic and grounded in human action "has the potential to explain emergence (Truex, Baskerville, and Klein 1999) and change in technologies and use" she also hints at the problems that many of these technology structurational models have introduced for that explanation. Giddens' (1984) weak notion of structure as "rules and resources recursively implicated in social reproduction...[that] exist only as memory traces" enables the emergent structurational cycle of structure and agency. This is in contrast to the approach of more structuralist social theorists, for whom structure becomes embedded in material artefacts. In structurational technology models, this approach implies that structure is inscribed (Latour 1991) into an information system. Typically this happens during the process of construction, with the finished product later influencing the behavior of its users: "designers incorporate... structures into technology...once complete the technology presents an array of social structures" (DeSanctis and Poole 1994). The problem with the approach is that it intervenes in the structurational cycle of structure and agency, undermining Giddens' explanation of emergence. Instead of locating structuration in social practice (individual and collective understandings and actions), emergence must now encompass the building and development of complex material artefacts, a much more cumbersome process. By separating the artefact from its use, and focusing on technologies-in-practice (the recurrent interaction that users have with technologies), Orlikowski relocates structure in the minds of users.

Technology structures are not external or independent of human agency; they are not "out there," embodied in technologies simply waiting to be appropriated. Rather they are virtual, emerging from peoples' repeated and situated interaction with particular technologies (2000, p. 407).

In this way, users are able to carry out tasks with the technology in the context of their individual and shared understandings of the technology (the structurational cycle of structure and agency). While enacting these practices, they have the power either to reenact (reinforce) them, or to change (transform) them. 
Two recent contributions to the literature point in the direction of our research. Hayes and Walsham (2000) used the notion of competing discourses to study the use of Lotus Notes in a UK company (finding that the political and normative context was deeply implicated in the reproduction of competing interpretations). In a study of the London insurance market, Heracleous and Barret (2001) linked discourse with communicative interactions (following the model of structuration theory) to explain organizational change processes in the context of an information technology implementation.

\section{THE IMPLEMENTATION OF SAP AT OMEGA}

\subsection{ERP Systems in Denmark}

Omega began its ERP journey in 1995. At that time, in common with many other companies, its experience with ERP systems was relatively insignificant, the IT function was primarily seen as technical, and IT systems had traditionally been developed to support existing procedures and processes. ERP systems, however, were different. They provided the opportunity for organizations to develop their procedures around the best practice ideas built into the systems. Implementing ERP systems, therefore, often requires considerable organizational change (Kohn 1996). The modular concept (one central database underlying many different modules supporting different organizational functions) was regarded as rather radical. Interest in ERP systems began to grow in Denmark in the early 1990s and sales continued for the remainder of the decade. The demand for consultants and technical experts with experience with ERP systems was high. In 1996 and 1997, the newspapers and the trade press praised these systems, reporting success stories about how the implementation of ERP systems had contributed to efficiency and cost saving. In 1998, 85 percent of the ERP companies said that then were pleased with their implementation, and 15 percent had got more than they expected (Deloitte Touche 1998). Danish companies, therefore, had no reason at that time to doubt that the implementation of an ERP system would improve performance and solve legacy system problems. The first negative reports appeared at the beginning of 1998 . The Danish audio firm Bang and Olufsen sent a briefing to the Danish stock exchange and the newspapers reporting its difficulties in implementing SAP, and its consequent poor financial results (Bang and Olufsen 1998/99). Other stories followed. A survey carried out in 2000 showed that 92 percent of the companies that had implemented an ERP system were unsatisfied with the outcome of the implementation and felt it had not lived up to expectations (PA Consulting 2000). Sales of ERP systems fell (partly because of market maturity and the 
disappearance of the $\mathrm{Y} 2 \mathrm{~K}$ problem), many ERP implementation consultants lost their jobs, and the demand for ERP skills decreased.

\subsection{Omega}

Omega is a Danish multinational production company with more than 1,000 employees. The company goes back more than 40 years, and is a significant player in both the Danish and the world markets. In 1995, the parent company was divided into four different functional departments, each of which had their own management structure and was more or less autonomous. The company had no tradition for outsourcing activities and had a high degree of horizontal integration. IT systems were commissioned individually by the different departments and subsidiaries, which all had their own software solutions. The IT department supported the different systems and departments with development, maintenance, and updates. The IT function's skill base was technical, and it was seen as the prime owner of IT issues, but it had never developed solutions from scratch and normally responded to requirements set by the different departments. As a result of strong growth in the beginning of the 1990s the company found it difficult to coordinate and manage processes across the different departments and internal communication came to be regarded as insufficient. In mid-1995, the managing director felt a need for better control and coordination. The idea of a new IT system was fostered. The perceived need was for a system that enabled better coordination and integration of data, that was able to improve customer service, and that would reduce the data entry effort.

\subsection{The ERP Implementation}

An ERP solution was chosen at Omega because of its advertised ability to integrate the different departments and functions. The reasons given were the high level of functionality and the flexibility built into the different modules. A limited selection of modules were seen as having the potential to fulfill the company's needs, and Omega could add other modules later if they became necessary. A team consisting of the production manager, one employee from the Sales Department and the IT manager was set up, and they spent three months investigating the ERP market for the system that would fulfill Omega's needs. The field was narrowed down to two, and the directors opted for SAP R/3 in January 1996. In February 1996, the implementation decision was taken at board level. A team of five middle line managers (one from each of the company's departments plus the IT manager) was appointed as the project team to be responsible for the implementation. The IT manager was appointed project 
manager. A steering committee was appointed consisting of senior managers, the project manager, members of the project group, and a number of super users from the departments. At the same time, a secretary was hired for the project on a temporary contract. The team was to make a project plan for the implementation containing goals, organizing principles, milestones, and budgets. It was decided to keep the implementation in-house and to build up internal ERP experience with the help of specialist external consultants. The chosen SAP modules were sales and distribution, material and production planning, and finance. The modules were to be implemented in all departments within the company: a big bang, or large footprint strategy. The go live date was set as January $1,1997$.

Written into the project plan was a statement that the implementation process should run until the system was in "normal" use in the main company's operations. Further projects would then be set up to implement SAP in the subsidiary companies during 1998 . No further consideration about the development of SAP was taken, beyond that the IT department (which was very technically oriented) should be responsibly for the technical maintenance of the system, as it had been for previous systems.

During the first couple of months of the implementation, the meetings in the project group were characterized by confusion. Members expressed loyalties to their own departments, had difficulty making decisions, and meetings were always longer than planned. The members of the project group began to question the IT manager's ability to manage the implementation and expressed discontent with the way he communicated to the steering committee. According to one of the members:

When we are having meetings in the project group and we agree on an issue, the project manager later says something different to the steering committee, just to please them. This is very confusing for us. Additionally he doesn't understand what the implementation is really about, he is only able to discuss the technical issues (Steering Group Member, Spring 1996).

The project manager also became unhappy, suggesting that

the implementation of SAP is more business development than system development, and requires a manager allocated 100\% to the implementation (First Project Manager, Spring 1996).

He immediately hired an SAP consultant (a technical expert who had been involved in many implementations around the world before settling in Denmark) to help the project group. One month later the consultant became the project 
manager, allocated full time to the project. Project meetings became much more incisive and now focused on describing business processes. The focus of the project changed from visionary discussions of future business possibilities to practical concerns related to going live on the due date. The project moved on rapidly, and the business case was finished by the end of June 1996.

\subsection{SAP Goes Live}

The first three months after going live were characterized as chaotic. Many employees were unable to use the system and others keyed in wrong data. Many of the newly designed processes were not adopted, and unforeseen complications arose with others. The result was a large backlog of production orders, with many late deliveries.

The majority of the implementation group saw their first priority as sorting out the many glitches and problems and achieving smooth running and operation of the modules that had been implemented. However, those working with SAP on a daily basis and the project manager were keen to expand the system and add new functionality if it would improve their operational performance. As the project manager commented,

we know that SAP would never be used without problems, there will always be things that we want to change or new functionality we would like to add. SAP is constantly releasing new products, which would be of interest to us (Second Project Manager, Spring 1997).

The implementation team often disagreed about what problems they should solve, why and when they should solve them, and whether the implementation had been a success. Two of the team members frequently expressed their discontent with the implementation and the system, considering the ongoing implementation to be the result of a top management decision, rather than because the system contributed to the performance of the organization. The financial result for 1997 was a deficit, the first in the history of the company. The managing director publicly attributed half of the deficit to the new SAP system. Despite this, managers were apparently satisfied with their work. The ERP system, they claimed, had made the company aware of weak spots in company processes, and was now seen as a potential strategic tool and catalyst for organizational change. According to the project manager the implementation was a success since 
it has given the company a tool to find out where it will be beneficial to make changes. The ERP system is a tool we can use to analyze the problems we have, but of course it doesn't solve the problems (Second Project Manager, Autumn 1997).

The outcomes of the ERP journey came as a surprise to many of the employees. Toward the end of 1997 the finance director expressed it this way:

I am surprised how huge this implementation has become, and how much it has changed our company. I was not aware of that before the implementation started, and it came as a surprise. But I have to say, if I have known it, I would have made the same decision today (Finance Director, Autumn 1997).

A year after the system became operational, the second project manager resigned from his job. He didn't think he could do anything more in the organization, and he had experienced resistance toward the system and his work, both from users and directors. A third project manager was appointed. He saw the IT system as something that should support operations in the organization but at the same time he had the opinion that the system and the abilities within it should be used. The system should be expanded wherever it would contribute positively to the performance of the organization. The new project manager said that he regarded the implementation as

a continuous process. It's not a project, which is a matter of solving problems, after which everything will run smoothly. But I do not think either the managing directors or the members of the implementation team understand it in this way. Maybe they will soon, I don't know (Third Project Manager, February 1998).

And, regarding the project group,

in the future $I$ expect that the implementation team will continue to meet, but not every week as today, try to keep the meetings very informal and at the same time involve the managing directors more. The aim for me is then to try to convince the rest of the organization that the implementation of SAP will not end. Because it is necessary to convince them, since not all employees have that understanding (Third Project Manager, February 1998). 


\subsection{Looking Back at the Implementation (Autumn 1998)}

Despite being well over budget, and well past the deadlines (at least in the subsidiary companies), the ERP system is today generally considered a success and Omega's managers cannot imagine the company without SAP. The managing director reflected back on the choice of system:

SAP was the most expensive, and therefore probably also the best. It was very difficult for us as managing directors to know what we said yes to, since we had limited understanding of the systems (Managing Director, Autumn 1997).

And on the implementation,

to be honest I have been quite surprised how huge this implementation has become, and I don't think it will end; as new modules are introduced, then the hardware has to be bigger (Managing Director, Autumn 1997).

However, when the sales and marketing director was asked to reflect of the implementation of SAP, he said:

I don't think that the project manager was tough enough to do what it takes. I think that we started out too early, and in 1996 we should have planned it better (Sales and Marketing Director, Autumn 1997).

\subsection{Further Developments}

A year after becoming the project manager, the third project manager was promoted to IT manager for the whole organization. The IT department's function thereby changed from being solely technical, to being both technical and business oriented. At the end of 1999, the employees that had worked full-time with the SAP system were relocated to departments to perform additional user skills building and alignment of the system with business needs. The new IT manager became involved in Omega's strategic planning process and the work of the business development department. Work in relation to the SAP system is now concentrated on reconfiguring the system when necessary, taking in new functionality and modules to improve the business performance, upgrading the system, and implementing SAP in subsidiaries (which took two years longer than originally planned and ended in late 2000). 


\section{CHANGING SENSE MAKING AT OMEGA: THREE ANALYSES OF THE ERP IMPLEMENTATION}

\subsection{Analysis 1: Technological Frames}

In the early days of the ERP planning process, the implementation was clearly thought of as a rather conventional, classic IT project. The procurement activities were handled as with other IT systems: identification of requirements, surveying the range of products, and comparing price and functionality. The implementation was set up as a project, with a command structure, responsibilities, budgets, and time schedules. The assumption was that the implementation of SAP would end, stable functioning of the new system would be achieved, at which point the project would finish and the implementation team be disbanded. Maintenance of the installed system would then be undertaken by the IT department. No prior consideration was made about organizational change, in particular process change, which might be the result of the best practice models embodied in the software. In other words, it was assumed that the ERP system had been chosen to meet the needs of the company, not that the company would have to change in order to fit in with the software. A style of rational analysis is evident (system selection against criteria, for example). We could characterize this way of sense making as a technology frame, following Orlikowski and Gash (1994): a sharply delineating way of sense making focused on a technology. This technological frame (most evident at the earlier round of data collection) characterizes the ERP implementation as a classic project, which can and should be planned in advance and run like other IT projects. In this frame, the ERP system is viewed as an administrative tool that should support existing processes and procedures. It is necessary and possible to allocate resources to the project in advance, and the appropriate managerial style is command and control. Managerial decisions about the implementation project can and should be based on rational analysis. The managerial objectives should be to bring the project in on time and on budget, and to realize a quick return on investment through efficiency gains.

\subsection{Analysis 2: Discourses}

However we note that this classical way of thinking is not independent of other discourses: the software solution was chosen partly on the reputation of the supplier, and in relation to what other companies were doing (a wider [mega] discourse in Denmark). The classical way of thinking about IT projects, although derived here from the empirical data, is also widespread in the aca- 
demic literature (Ben-David and Raz 2001; Boyd 2001; Motwani et al. 2002; Pillai and Rao 2000) and consultancy and teaching in IT project management. Perhaps we should think of it as a grand discourse operating at this period. Unlike the Notes example analyzed by Orlikowski (1992), the classical technological frame of reference at Omega was not particular to one social group, but widely held among managers, technical staff, and users. Although this classical model is clearly the dominant discourse at the beginning of the implementation, the project meetings were actually concerned with another style of sense making, which the project manager refers to as business development. Although able to function in this competing discourse, he was clearly not happy with it, and switched back to the more comfortable discourse in other forums, to the annoyance of other project team members.

An alternative sense-making strategy can be seen gradually asserting itself, and is much more pronounced in the later round of interviews. The chief executive's retrospective reflections indicate that the system was of sufficient scope and complexity to make it virtually impossible for decision makers to understand the implications for the company. It could not, therefore, be rationally analyzed or planned. Now the scope of the implementation is seen as much wider (the finance director comments on the wide impact of the system), and several actors expect it to be an evolutionary process, not a finite one. The project manager explicitly dissociates the implementation from the conventional idea of a project. Process and business issues are very much on the agenda (this is the business development that features in project meetings). The role of the project manager has changed (he now sees his role as education and facilitation), and his success criteria are redefined as the ability to learn about the operation of the company, rather than directly solving the company's problems, or contributing to efficiency. SAP is at the heart of the company's improvement initiatives.

The two different sense-making styles are set out in Table 1 .

Even though the second discourse is predominant at the later stages of the implementation, some actors retain the earlier sense-making scheme. For instance, the sales and marketing director characterizes the implementation as a project lacking sufficient command and control, and suffering from poor planning. Dissatisfied members of the project team also attribute the continuation of the project to bad management decision making. However, many of the same actors, who were operating within the classical technological discourse, later operated equally comfortably within the IT driven organization change initiative discourse. We should also note that wider discourse within the business community also starts to change with the first reports of poor results as a consequence of ERP implementations. 
Table 1. Competing Technological Discourses at Omega

\begin{tabular}{|l|l|l|}
\hline \multicolumn{1}{|c|}{ Issues } & \multicolumn{1}{|c|}{$\begin{array}{c}\text { Technology Discourse 1: } \\
\text { Classical IT Project }\end{array}$} & $\begin{array}{l}\text { Technology Discourse 2: IT Driven } \\
\text { Organizational Change Initiative }\end{array}$ \\
\hline $\begin{array}{l}\text { Understanding of } \\
\text { ERP implemen- } \\
\text { tation }\end{array}$ & $\begin{array}{l}\text { The implementation is a classic } \\
\text { project, which can and should be } \\
\text { planned in advance and run like } \\
\text { other IT projects }\end{array}$ & $\begin{array}{l}\text { The implementation is a evolutionary } \\
\text { change process affecting organiza- } \\
\text { tional life, and should respond to } \\
\text { changing objectives, conditions, and } \\
\text { unfolding circumstances }\end{array}$ \\
\hline $\begin{array}{l}\text { The role of } \\
\text { system }\end{array}$ & $\begin{array}{l}\text { The ERP system is an adminis- } \\
\text { trative tool to support existing } \\
\text { processes and procedures }\end{array}$ & $\begin{array}{l}\text { The ERP system is a strategic } \\
\text { resource that facilitates changes in } \\
\text { processes and procedures }\end{array}$ \\
\hline $\begin{array}{l}\text { Resource } \\
\text { allocation }\end{array}$ & $\begin{array}{l}\text { It is necessary and possible to } \\
\text { allocate resources in advance }\end{array}$ & $\begin{array}{l}\text { Evolving resource needs dependent } \\
\text { upon unforeseeable evolving } \\
\text { conditions }\end{array}$ \\
\hline $\begin{array}{l}\text { Management } \\
\text { praxis }\end{array}$ & Command and control & Facilitation and inspiration \\
\hline Guiding logic & $\begin{array}{l}\text { The implementation should be } \\
\text { controlled according to rational } \\
\text { analysis }\end{array}$ & $\begin{array}{l}\text { The implementation is complex and } \\
\text { difficult to analyze, and therefore } \\
\text { managed on evolving best guesses }\end{array}$ \\
\hline Success criteria & $\begin{array}{l}\text { On time and on budget, } \\
\text { efficiency gains }\end{array}$ & Organizational learning \\
\hline
\end{tabular}

\subsection{Analysis 3: Practice Lens}

The practice lens (structurational) analysis explicitly focuses on the relationship between sense making and action, and on emergence. The decisions and actions taken at the early stage of the implementation (for example, the selection of system, organization of the project, and choice of project manager) are largely consistent with this dominant classical discourse. However, if the implementation was largely viewed as a classical IT project, and planned and run after these principles, its perceived outcomes are difficult to interpret as successful using this frame of reference. SAP's introduction clearly caused major disruption to the normal running of the company and had a disastrous affect on its finances, at least in the short term. Although the implementation went live on the scheduled date, at the insistence of management, there were many unresolved technical problems and resistance toward the use of the system (which meant that the project team could not be disbanded), and it was well over budget. Subsequent implementations in the subsidiary companies ran into difficult problems and went many months over their deadlines. None of the success criteria were met, and if actions and the perceived outcomes of those actions were to be interpreted through the classical discourse, actors would have to conclude that the project was under-resourced, badly planned, and poorly 
controlled, and that SAP was not successful at supporting the company's processes and delivering efficiency savings. Moreover the managerial decisionmaking process leading to its adoption and subsequent continued support would come into question. Indeed, some actors did make at least some of those judgments based upon the older dominant discourse. Clearly these interpretations are difficult to sustain on an organization-wide basis, and conflict badly with value systems in other discourses, such as the managerial discourse of responsibility, profit, and shareholder value or the technical discourse of engineering competence. Interpretation of the pattern of actions and perceived consequences through the newer discourse is much more comfortable

To sum up: In 1996, the general organizational and managerial understanding in Omega was that SAP should be a tool to support existing processes and procedures to increase control, coordination, and efficiency. This view was also shared by the wider community in Denmark. However, late in 1997, the general organizational understanding began to change. This was in line with the organization's own difficulties, and also in line with a more general development reported in Denmark. The senior managers instead began to interpret the ERP implementation as a IT driven organization change initiative and the ERP system as a potential strategic resource, in need of strategic attention and an ERP manager with the status and resources to contribute to the overall management process.

\section{THEORY COMPARISON AND DISCUSSION}

Having described a case history in which one form of technological discourse is replaced by another, we now return to the theoretical argument. Reflecting on the empirical story and the unfolding analyses, we should first observe some broad similarity between the theoretical constructs: frame of reference, discourse, and structure. In each case, the construct includes a social (shared) conceptual apparatus for the interpretation of phenomena and the assignment of meaning to them. In the case of technological frames, the shared understanding belongs to an identifiable social group or community of practice in an organization, whereas the other constructs invite consideration of a variety of shared understandings at various levels of social grouping, from the individual to the societal. The discourse construct invites consideration of a distinguishable organizational discourse (or perhaps several) and of a ruling or dominant discourse. The constructs differ in the extent to which they focus on meaning: very largely in the case of technological frames, but less in the case of the practice lens, where other concepts such as norms, rules, and resources are also employed. Whereas the practice lens construct tends to focus attention on the development of homogenous structures (in keeping with its structurational 
roots), the other constructs enable the possibility of distinguishing complementary or competing perspectives. The discourse construct, in particular, offers a sophisticated view of the individual's ability to navigate around perspectives in a self-aware manner, in contrast to the more limited technological frame view of an unaware individual caught in a constraining frame of reference. However, while the discourse construct and the technological frame construct point at differing explanations of phenomena, they provide no explanation of emergence or change. It is not clear why different perspectives should exist, why one explanation should predominate in a given situation or, how that would change. The practice lens offers an emergent picture of individual and shared understandings evolving as they generate actions which in turn reinforce or transform understandings in a cyclical manner. The key element is the explicit addition of actions (technology in use) into the picture. The technological frames construct focuses on understandings, not actions, although actions can be phenomena interpreted through the frame. The discourse construct includes interactions (casting these as dialogues that facilitate the linguistic negotiation of meanings). Actions are much more visible in the practice lens construct. Here actors instantiate, (act out) their conceptual schema, creating actions and interactions that can be interpreted and negotiated with other actors, and which corroborate or interrogate those schema. Instantiations can reinforce those conceptual schema, in which case technological practice is likely to stay the same, or transform them, in which case technological practice is likely to change.

This comparison is formalized in Table 2.

Table 2. Comparison of Technological Frames, Discourse, and Practice Lens Constructs

\begin{tabular}{|l|l|l|l|}
\hline & Technological Frame & \multicolumn{1}{|c|}{ Discourse } & \multicolumn{1}{|c|}{ Practice Lens } \\
\hline Primary focus & $\begin{array}{l}\text { differing interpreta- } \\
\text { tions of technology }\end{array}$ & $\begin{array}{l}\text { lonstruction of indi- } \\
\text { vidual and shared } \\
\text { meanings through } \\
\text { language }\end{array}$ & $\begin{array}{l}\text { relation of individual } \\
\text { and shared conceptual } \\
\text { schema (structure) to } \\
\text { actions and interactions } \\
\text { in technology context }\end{array}$ \\
\hline Technology focus & Yes & No & Yes \\
\hline $\begin{array}{l}\text { Level of social } \\
\text { grouping }\end{array}$ & social group & individual-society & individual-society \\
\hline $\begin{array}{l}\text { Incorporates } \\
\text { actions }\end{array}$ & No & $\begin{array}{l}\text { incorporates social } \\
\text { interactions }\end{array}$ & Yes \\
\hline $\begin{array}{l}\text { Competing } \\
\text { perspectives }\end{array}$ & Yes & Yes & No \\
\hline $\begin{array}{l}\text { Explanation of } \\
\text { emergence }\end{array}$ & No & No & Yes \\
\hline
\end{tabular}


Technological frames helped us to understand and sharply delineate the contrasting technology perspectives at Omega. However, they did not help us understand how one set of explanations should predominate, or why the majority of actors would change their sense-making constructs. Studying discourse gave a much more sophisticated explanation for the existence of multiple sensemaking perspectives, and how different actors could shift between them, but still no explanation of emergence or change. Here we looked for a theoretical approach in which emergence was fundamental, and chose structuration theory, in particular the practice lens of Orlikowski (2000). This gave us an explanation of emergence, by incorporating the structurational cycle of structure and agency. Now we could begin to build an explanation of why sense making at Omega should change so radically. Each of these theoretical approaches was useful for explaining parts of the story, but none gave a complete explanation.

\section{THEORETICAL MODEL: DOMINANT TECHNOLOGICAL DISCOURSES AND ACTION-PARADIGMATIC SHIFTS IN SENSE MAKING}

In this section, the experience of the change in sense making of the Omega ERP implementation is generalized to theory. Concepts from the three theoretical frameworks introduced earlier are woven together to produce a generalized explanation of the empirical story.

The discourse space represents the sum total of available discourses - many and at many different levels. Technological discourse is discourse carried on around, and principally concerning, a technological object, here primarily an information system (this technology focus is adopted from the technological frames construct, as is the notion that competing technological discourses can be delineated). Technological discourses do not exist in isolation from other discourse (for instance, society-wide discourse), but relate and respond to them. The dominant technological discourse represents the way of thinking that predominantly guides decision making and the taking of action. This may reflect how widely the dominant technological discourse is held, but may also reflect the power of those who adopt it. It also provides the frame through which action and outcomes are interpreted and fed back into the shared understanding. The dominant technological discourse will normally coexist with complementary or competing technological discourses - alternative sense-making systems that people use, but primarily to critique or challenge the dominant sense-making. The dominant technical discourse leads to actions (for instance, the purchase of a computer system) and outcomes (for instance the annual company results). We do not mean to imply some simple linear causal chain of decisions, actions, 
and outcomes (although this may be a feature of some organizational discourse used to interpret these factors). However, a dominant technological discourse will legitimate some actions and invalidate others, and is thus likely to produce a multidimensional pattern of related actions (such as an IT project, the hiring of expert consultants, project management activities, budgets, etc.). There will also be a multidimensional pattern of intended and unintended outcomes (such as accounts, hardware and software installations, new process descriptions, new hires and redundancies, user satisfaction and resistance). The attribution of cause and effect to actions and outcomes is seen as primarily interpretive and located at the level of discourse. Actions and outcomes can be interpreted as congruent or incongruent with the dominant technological discourse. A pattern of minor incongruities is likely to reinforce the dominant discourse (for instance, a project that is perceived as poorly controlled and misses its deadlines is likely to lead to calls for better control). However, repeated major incongruities open the way for other discourses, which offer more consistent sense making. These may then become, at least temporarily, the dominant discourse.

This process should also be seen in relation to other important discourses. The major factor in the rise and fall of a dominant technological discourse may not be consistency, but comfort in the light of more important discourses. Thus, an IT project that negatively affects a company's profitability may need to be reinterpreted in managerial discourse. Congruence between perceptions of actions and outcomes and the dominant technological discourse is like to result in reenactment of technological practice. Major incongruence is likely to result in transformation of technological practice. This change process somewhat resembles that described by Kuhn (1962) in the context of scientific revolutions, so we label it a paradigm shift. The theoretical model is represented diagrammatically in Figure 1.

In the case of Omega, we see that the dominant classical technological discourse produced a pattern of actions in which the ERP implementation was organized as a conventional IT project. Some actors, however, saw the project as business development even in the early stages. Many of the outcomes (disruption instead of increased efficiency, a continuing project rather than a finished one) were hard to rationalize using the classical interpretive scheme. Managers probably found this discourse hard to sustain at board meetings (where the company's loss was partly attributed to the ERP system), in the face of the dominant managerial discourse of control, efficiency, and shareholder value. In addition, other related discourses (such as the wider mega-discourse about ERP systems in Denmark) changed. Gradually the dominant classical technological discourse was replaced by a more plausible and comfortable discourse, in which the ERP implementation was viewed as an evolutionary ITdriven organizational change initiative. Some actors, however, retained the old discourse, characterizing the project as badly planned and controlled, and the outcomes as inefficient. 


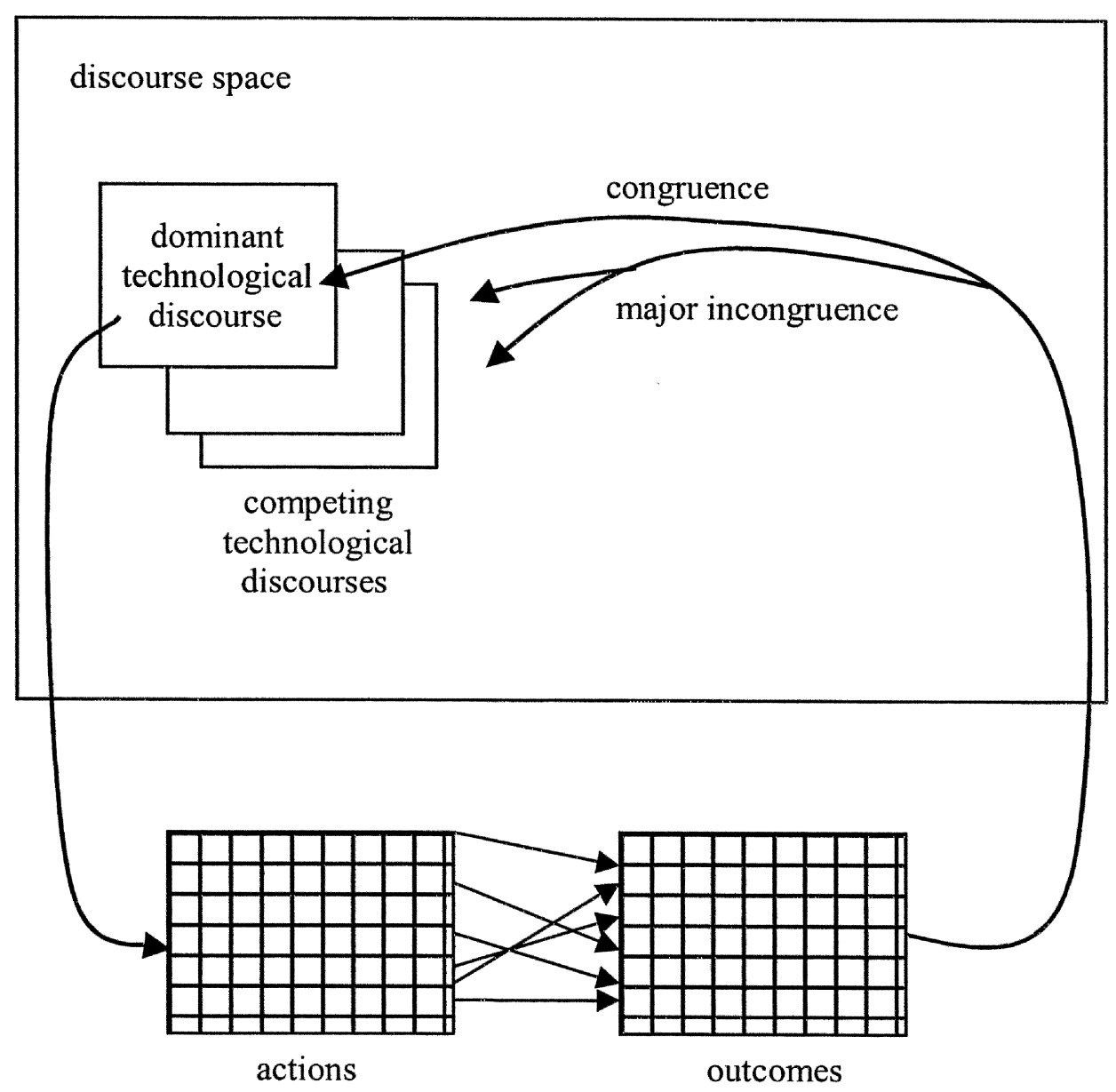

an evolving multidimensional pattern of actions and outcomes

Figure 1. Theoretical Model: Dominant Technological Discourse and Action

\section{CONCLUSIONS}

While studying the implementation of an ERP system in a medium-sized Danish production company, we observed a change in sense making. Of course, our own sense making also changed. We came, for example, to think that the word implementation was inappropriate for these large ERP projects and used the word journey instead (Kræmmergaard and Rose forthcoming). During the course of Omega's journey, many of the actors came to think in a different way about their experiences with SAP. In trying to analyze and explain the change, we adopted theoretical concepts from three different sources. The information system focus of Orlikowski and Gash's (1994) technological frame construct fitted our data well, and helped us to distinguish clearly between different styles of sense making at Omega. However, the different sense-making styles were not necessarily associated with different social groups, but held quite widely over 
the organization at different times. Actors (for example, the first project manager) were able to move between different social groups and adapt. Nor was the technological sense making unaffected by other of sense making (for example, managerial), or by wider understandings drawn from developing experience with ERP systems in Denmark. For these reasons we preferred the discourse construct, and used the phrase dominant technological discourse to refer specifically to the governing style of sense making focused on an information system.

At Omega, we were able to distinguish between a classical IT project technological discourse and a different IT-driven organizational change initiative discourse. The question remained: how and why should the dominant discourse change? By relating sense-making to action, following the theoretical direction of Orlikowski and Robey's (1991) work with structuration theory, we were able to understand how patterns of actions were dependent on prior sense making and how the actions themselves instantiated sense making. This emergent technological practice can reenact itself (staying essentially the same) or change. At Omega, the patterns changed. The dominant classical technological discourse began to produce inconsistent and uncomfortable sense making of the SAP project, and was slowly replaced by a different way of thinking and acting. Nevertheless, some actors continued to think in the old discourse, explaining the implementation as a badly managed IT project. In theoretical terms, we explained this change in terms of congruence or incongruence between actions/ outcomes and the dominant discourse, while suggesting that the technological discourse was affected by other discourses and that the actors' comfort in relation to those other discourses was also important.

The eventual theoretical model describes the discourse space (all of available discourses in the situation) and the dominant technological discourse. Actions taken in the light of understanding gained through the dominant technical discourse produce outcomes that are consistent or inconsistent with it, and more or less comfortable in other discourses and therefore reinforce or undermine it. A dominant discourse, which is sufficiently undermined, can be replaced by another, which produces better consistency or comfort, in the manner of a paradigm shift.

While the theoretical model can be used to explain the shift in sense making at Omega, we consider that further research is necessary to establish whether it can be generalized to other technology related situations.

\section{ACKNOWLEDGEMENT}

This work was supported in part by funding from the Danish Research Agency under the PITNIT Project, grant number 9900102. 


\section{REFERENCES}

Alvesson, M., and Karreman, D. "Varieties of Discourse: On the Study of Organizations through Discourse Analysis," Human Relations (53:9), September, 2000, pp. 1125-1149.

Alvesson, M., and Willmott, H. Making Sense of Management. London: Sage, 1996.

Argyris, C., and Schön, D. Organizational Learning: A Theory of Action Perspective. Reading, MA: Addison-Wesley, 1978.

Barley, S. R. "Technology as an Occasion for Structuring: Evidence from Observation of CT Scanners," Administrative Science Quarterly (31), 1986, pp. 78-108.

Bang and Olufsen. Annual Report. Copenhagen, 1998/99.

Ben-David, I., and Raz, T. "An Integrated Approach for Risk Response Development in Project Planning," Journal of the Operational Research Society (52:1), 2001, pp. 14-25.

Berger, P. L., and Luckmann, T. The Social Construction of Reality: A Treatise in the Sociology of Knowledge. New York: Anchor Press, 1966.

Bijker, W. E., Hughes, T. P., and Trevor, P. (eds.). Technology and Culture. The Social Construction of Technological Systems: New Directions in the Sociology and History of Technology. Cambridge, MA: MIT Press, 1987.

Bijker, W., and Law, J. (eds.). Shaping Technology/Building Society: Studies in Sociotechnical Change. Cambridge, MA: MIT Press, 1994.

Borenreider, I. "New Forms of Organizations: The Need for Managing Diversity," paper delivered at the Third International Conference on Organizational Discourses: Pretexts, Subtexts, and Contexts, Kings College, London, UK, 1998.

Boyd, A. "The Five Maxims of Project Satisfaction," Aslib Proceedings (53:10), 2001, pp. 423430.

Callon, M. "Society in the Making: The Study of Technology as a Tool for Sociological Analysis," in W. E. Bijker, T. P. Hughes, and T. Pinch (eds)., The Social Construction of Technological Systems. Cambridge, MA: MIT Press, 1987, pp. 83-103.

Casey, C. Work, Self and Society: After Industrialism. London: Routledge, 1995.

Checkland, P. B., and Davies, L. "The Use of the Term 'Weltanschauung' in Soft Systems Methodology," International Journal of Information Management (13), 1986, pp. 109-115.

Ciborra, C. (ed.). From Control to Drift. Oxford: Oxford University Press, 2000.

Deloitte Touche Consulting. Danske erfaringer med implementering af integrerede informationssystemer. København, Danmark: Deloitte Touche Consulting, 1998.

Derrida, J. (ed.). Différance, Margins of Philosophy. Chicago: University of Chicago Press, 1982.

DeSanctis, G., and Poole, M. S. "Capturing the Complexity in Advanced Technology Use: Adaptive Structuration Theory," Organization Science (5:2), 1994, pp. 121-147.

Douglas, M. How Institutions Think. London: Routledge and Kegan Paul, 1987.

Eden, C. "Cognitive Mapping, European Journal of Operational Research (36), 1988, pp. 1-13.

Edwards, P. N. The Closed World: Computers and the Politics of Discourse in Cold War America. Cambridge, MA: MIT Press, 1995.

Eisenhardt, K. "Building Theories from Case Study Research," Academy of Management Review (15:4), 1989, pp. 532-550.

Giddens, A. The Constitution of Society. Cambridge, MA: Polity Press, 1984.

Goffman, I. Frame Analysis. New York: Harper and Row, 1974.

Grint, K., and Woolgar, S. The Machine at Work. Cambridge, MA: Polity Press, 1997.

Hayes, N., and Walsham, G. "Competing Interpretations of Computer-Supported Cooperative Work in Organizational Contexts," Organization (7:1), 2000, pp. 49-67.

Heracleous, L., and Barrett, M. "Organizational Change as Discourse: Communicative Actions and Deep Structures in the Context of Information Technology Implementation," Academy of Management Journal (44:4), 2001, pp. 755-778.

Hopper, P. “Emergent Grammar,” Berkeley Linguistics Society (13), 1987, pp. 139-157. 
Kræmmergaard, P., and Rose, J. "Managerina Competencies for EPR Journeys," Information Systems Frontiers, forthcoming.

Kohn, B. "Implementering af rammesystemr til økonomistyring - Glem hvad du har lært - det meste er forkert," Økonomistyring og Informatik, Copenhagen Business School, Denmark, Volume 11 årgang, Number 6, 1996.

Kuhn, T. The Structure of Scientific Revolutions. Chicago: Chicago University Press, 1962.

Latour, B. "Technology Is Society Made Durable," in J. Law (ed.), A Sociology of Monsters: Essays on Power, Technology and Domination. London: Routledge, 1991, pp. 103-131.

Law, J. (ed.). A Sociology of Monsters: Essays on Power, Technology and Domination. London: Routledge, 1991.

Monteiro, E., and Hanseth, O. "Social Shaping of Information Infrastructure," in W. J. Orlikowski, G. Walsham, M. Jones, and J. I. DeGross (eds.), Information Technology and Changes in Organizational Work. London: Chapman \& Hall, 1996.

Motwani, J., Mirchandani, D., Madan, M., and Gunasekaran, A. "Successful Implementation of ERP Projects: Evidence from Two Case Studies," International Journal of Production Economics (75:1/2), 2002, pp. 83-96.

Myers, M. D. "Critical Ethnography in Information Systems," in A. S. Lee, J. Liebenau, and J. I. DeGross (eds.), Information Systems and Qualitative Research. London: Chapman \& Hall, 1997, pp. 276-300.

Orlikowski, W. J. "The Duality of Technology: Rethinking the Concept of Technology in Organizations," Organization Science (3:3), 1992, pp. 398-429.

Orlikowski, W. J. "Using Technology and Constituting Structures: A Practice Lens for Studying Technology in Organizations," Organization Science (11:4), July-August, 2000, pp. 404-428.

Orlikowski, W. J., and Gash, D. C. "Technological Frames: Making Sense of IT in Organizations," ACM Transactions on Information Systems (12:2), 1994, pp. 174-207.

Orlikowski, W. J., and Robey, D. "IT and the Structuring of Organizations," Information Systems Research (2:2), 2, 1991, pp. 143-169.

PA Consulting Group. Unlocking the value of ERP. Copenhagen, 2000.

Pillai, A. S., and Rao, K. S. "High Technology Product Development: Technical and Management Review System," International Journal of Technology Management (19:7/8), 2000, pp. 685-698.

Rose, J., and Scheepers, R. "Structuration Theory and Information Systems Development; Frameworks for Practice," paper delivered at the European Conference on Information Systems, Bled, Slovenia, 2001.

Truex, D. P., Baskerville, R., and Klein, H. K. "Growing Systems in an Emergent Organization," Communications of the ACM (42:8), August 1999, pp. 117-123.

Walsham, G. "Interpretive Case Studies in IS Research: Nature and Method," European Journal of Information Systems (4), 1995, pp. 74-81.

Walsham, G. Interpreting Information Systems. Chichester: Wiley, 1993.

Weick, K. E. The Social Psychology of Organizing. Reading, MA: Addison Wesley, 1979.

Weick, K. E., and Bougon, M. G. "Organizations as Cognitive Maps: Charting Ways to Success and Failure," in H. P. Sims and D. A. Giola (eds.), The Thinking Organizations: Dynamics of Organization Social Cognition, San Francisco: Jossey-Bass, 1986, pp. 102-135.

\section{About the Authors}

Jeremy Rose was born in Manchester, England, won an exhibition to read English at Cambridge, and subsequently trained to be a musician at the Royal College of Music in London. After working for some years for the Rambert 
Dance Company and Music Projects London, his career was cut short by injury and he retrained at Lancaster, gaining his M.Sc. in Information Management with distinction and later returning for his Ph.D. He collaborated with Peter Checkland on research projects and has recently been working with colleagues at Cambridge and Georgia State University. He is currently associate professor in the department of computer studies at Aalborg University. He has published in management, systems, and IS forums, and his doctoral studies focused on intranet development. Other research interests include IS development and evaluation, systems methodology, structuration theory and actor network theory, BPR, knowledge management, and the health service. Further details and some publications available at http://www.cs.auc.dk/ jeremy/. Jeremy can be reached by e-mail at jeremy@cs.auc.dk.

Pernille Kræmmergaard was born in Denmark in 1968, and graduated as a Master in International Business Economics in 1993. After working some years for a Danish industrial company, she returned to academia to gain her $\mathrm{Ph} . \mathrm{D}$. in technological and organizational change from Aalborg University in 2001. She has recently collaborated with colleagues from the Department of Computer Science at Aalborg University, the Department of Economics, Aarhus University, and the Department of Informatics, Aarhus Business School. She is currently an assistant professor at the Centre of Industrial Production at Aalborg University. She has published in production management, organizational change, and IS forums, and her doctoral studies focused on ERP implementation. Other research interests include organizational and technological change, supply-chain management, action research and methodology, and implementation of complex development projects. Pernille can be reached by e-mail at pkj@iprod.auc.dk. 